\title{
Individual differences of sensitivity of tennis players to injustice situations from the perspective of the five-factor model of personality Big Five Theory
}

\author{
Adriana Kaplánová* \\ Faculty of Physical Education and Sport, Comenius University in Bratislava, Bratislava, Slovak Republic
}

Copyright: (C) 2018 A. Kaplánová. This is an open access article licensed under the Creative Commons Attribution License (http://creativecommons.org/licenses/by/4.0/).

\begin{abstract}
Background: The reason why some people reflect an increased incidence of injustice and others are barely able to remember the injustice situation is embedded in the meaning that a person attributes to these situations based on their subjective evaluation. Therefore, in this context, we consider it meaningful to mention Bruner's postulated relationship between the dynamics of personality and the dynamics of perception showing that a discrepancy in the perception of a human being may be explained in the sphere of personality structure. Objective: The study aims to investigate the different level of sensitivity of tennis players towards injustice situations. The variability of sensitivity level against injustice was investigated from the perspective of the five-factor model of personality. Methods: The research sample consists of 61 tennis players ( 33 women, 28 men) aged from 20 to 24 (21.75 \pm 1.40 years). The personality structure of tennis players was investigated by the NEO-FFI inventory (Ruisel \& Halama, 2007). Their level of sensitivity to injustice was investigated by the questionnaire of sensitivity to injustice - SVN (Lovaš, 1995). Results: Tennis players who are highly sensitive to injustice have a high level of emotional lability and those who have a low sensitivity to injustice have a high level of emotional stability $(r=.41 ; p=.001)$. The results of research have also shown that the level of conscientiousness, agreeableness and openness to experience does not have significant effect on their overall sensitivity to injustice, however, we have found significant relationship in terms of emotional component towards sensitivity to injustice $(r=.29 ; p=.033)$ in the case of extrovert/introvert. Conclusion: The results of our research have shown that the sensitivity to injustice of tennis players varies according to the level of emotional lability/stability.
\end{abstract}

Keywords: sport psychology, personality traits, tennis, early adulthood

\section{Introduction}

The fact that some people reflect the increased incidence of injustice situations and others are barely able to remember the injustice situation is a consequence of subjective perception of injustice (Lovaš, 1995). Justice behavior respects habits and authorization, as long as a person's behavior is in accordance with the law (Miller, Coleman, Connolly, \& Ryan, 1995). In addition to the moral principle requesting respect for legal standards, as justice shall be regarded even the virtue of respect the rights of others (Durozoi \& Roussel, 1994). Therefore, any violation of eligible entitlements, attribution of responsibility or apportion blame to another

\footnotetext{
* Address for correspondence: Adriana Kaplánová, Faculty of Physical Education and Sport, Comenius University in Bratislava, Nábrežie armádneho generála Ludvíka Svobodu 42e98/9, 814 69 Bratislava, Slovak Republic. E-mail: kaplanova8@uniba.sk
}

subject can be considered as unfair behavior violating not only legal, but even social standards (Mikula \& Schlamberger, 1985).

A person having a high level of sensitivity to injustice acting as a victim is generally interested in justice as a result of which they react to an unjust situation with an increased sensitivity (Hamlin, 2014; Schmidt $\&$ Somerville, 2011). The perception of injustice provides a very strong motivation for people to behave so as to prevent injustice and repeatedly restore justice (Baumert, Otto, Thomas, Bobocel, \& Schmitt, 2012). Currently, there is still uncertainty whether human motivation to restore justice is caused by controlled cognitive processes and thinking (Ellis \& MacLaren, 2005; Žitný \& Halama, 2011) or it is due to rapid, affective, automated reactivity, including empathy (Batson, 2012; Decety \& Cowell, 2014; Decety \& Yoder, 2016; Gleichgerrcht \& Young, 2013; Yoder, Porges, \& Decety, 2015). We can consider the sensitivity to injustice as 
relatively stable, but at the same time as a constantly evolving variable which is to some extent influenced by the previous experience of justice or injustice (Wijn $\&$ van den Boss, 2010). Therefore, the sensitivity to injustice can be regarded as a personality trait, which predisposes a person to react to situations in a relatively steady manner and also predict the behavior of a person (Jensen-Campbell \& Graziano, 2001; Lovaš \& Wolt, 2002; Salbot, Nábělová, \& Kaliská, 2012). There are several approaches that contribute to the conceptualization of many theories, and thus create different typologies of personality. For example, Factor-rys theory describes individual dimensions of personality on the basis of which it assumes that a person reaches a certain degree on the continuum of above mentioned dimensions (Kafka, Kovaničová, \& Pálová, 2004). The most widely used personality model in the area of sport is five-factor model of personality, namely, the Big Five consisting of five dimensions: extrovert/introvert, consciousness, agreeableness, emotional lability/emotional stability, and openness to experience. This model deals with a personality, in particular due to its stability over time and multicultural relevance as supported by NEO inventories, NEO-PI, NEO-PI-R, NEO-FFI that have been translated into more than 30 languages throughout the world (Digman, 1989; Jang, McCrae, Angleitner, Riemann, \& Liwesley, 1998; McCrae \& Costa, 1997; Mirzaei, Nikbakhsh, \& Sharififar, 2013).

Tennis success is characterized not only by the level of sport skills of athletes and their professional sports readiness, but also by a number of factors influencing an individual behavior such as emotional control, focus on action, independence, or responsibility of tennis players (Wagstaff, 2014; Wilson, 2001). The combination of personality traits depending on a type of sport is one of factors predicting overall performance of athletes. Emphasizing the individual differences of athletes and their training can significantly affect sport performance and subsequently better prepare athletes for conditions of top-level sport (Aidman, 2007; Allen, Greenless, \& Jones, 2013; Allen \& Laborde, 2014; Conway, 2016; Demir \& Yazici, 2015; Mirzaei et al., 2013).

The results of research conducted via the sample of athletes have shown a positive correlation of sport performance with openness to experience, and a negative correlation of sport performance with neuroticism (Courneya \& Hellsten, 1998; Piedmont, Hill, \& Blanco, 1999; Wagstaff, 2014). On the basis of the results from the research a tennis player's personality predisposes the achievement of excellent performances, what can be described as emotionally stable and extrovert personality classified as a sanguine type (Gregor, 2004). Extroverts tend to have a positive perception of interpersonal experience, while in comparison to introverts; they experience pleasant emotions more often (Argyle \& Lu, 1990; Pavot, Diener, \& Fujita, 1990; Watson \& Clark, 1992). Emotively stable people are relatively capable of controlling and managing stressful situations in comparison to emotionally unstable individuals, who tend to behave rather hostilely in these situations with accompanying negative emotions (David \& Suls, 1999; Gunthert, Cohen, \& Armeli, 1999; Hřebičková \& Urbánek, 2001; O’Brien \& DeLongis, 1996).

From the above, it is obvious that the reason why some tennis players reflect an increased incidence of injustice and others are barely able to remember the injustice situation is embedded in the meaning that a person attributes to these situations. In this context, we consider it meaningful to discuss Bruner's postulated relationship between the dynamics of personality and the dynamics of perception, where a discrepancy in the perception of people can be explained precisely in the sphere of the personality structure (Lovaš \& Pirháčová, 1996; Žitný \& Halama, 2011).

The present study aims to test the hypothesis whether there is a relationship between the sensitivity to injustice and the personality structure of tennis players from the perspective of the five-factor personality, the Big Five Theory. In the first hypothesis, we assume that there is a negative relation between extrovert, conscientiousness, agreeableness, openness to experience, and sensitivity to injustice. In the second hypothesis, we assume that we will find a positive relationship between emotional lability and sensitivity to injustice.

\section{Methods}

The research sample consisted of 61 tennis players (33 women, 28 men) aged from 20 to 24 with average age of $21.75 \pm 1.40$ years. The sporting age of tennis players indicates that the number of years of active play in our research has reached $11.45 \pm 2.70$ years. The research involved tennis players training in two phases, i.e., twice a day, from five to six days per week throughout the year.

Tennis players responded to 32 items of the questionnaire of sensitivity to injustice - SVN (Lovaš, 1995), where they recorded answers on a linear 4-point scale (1 - almost never, 2 - rarely, 3 - often, 4 - very often). An indicator of injustice was the level of angry reactions (the emotional component) and the frequency of occurrence of an injustice situation (cognitive component) to different stressful and tense situations (Lovaš, 1995). The questionnaire of sensitivity to injustice SVN was selected to determine the degree of sensitivity to injustice of tennis players, in particular because it monitors parameters such as an occurrence of an unfair situation and anger intensity. The personality 
structure of tennis players has been identified with a shortened version of the inventory NEO-FFI (Ruisel \& Halama, 2007) that has been translated into more than 30 languages across the world, what ensures wider comparability of results even in different areas of sport. The tennis players recorded the answer on a linear 5-point scale ( 0 - strongly disagree, 1 - disagree, 2 - neutral, 3 - agree, 4 - strongly agree).

A snowball technique used in cases with difficult target group was used to collect data. A member of the required group, who in our case is a tennis trainer, was asked to contact others or potential respondents who met the criteria of our research intention. Data were collected anonymously, with informed consent of the respondents. The study design was approved by the local Ethics Committee. The players involved in the research were informed about the goals and objectives of data collection and their use for research purposes.

The study used the correlational research design in order to assess the closeness of relationships between the personality structure of tennis players and their sensitivity to injustice. We used a correlation analysis with Pearson correlation coefficient representing the linear dependence between the two variables which is used in the normal distribution of data. The tightness of relationship was assessed for $5 \%$ and $1 \%$ of the level of statistical significance. We used the SPSS statistical program (Version 23 for Windows, IBM, Armonk, NY, USA) to process and evaluate the obtained data.

\section{Results}

In Table 1 we present basic descriptive characteristics: mean, standard deviation, also maximum and minimum score value achieved by the tennis players in the questionnaire of sensitivity to injustice - SVN (Lovaš, 1995) and in the five-factor personal inventory NEOFFI (Ruisel \& Halama, 2007). The results of correlation analysis between the personality structure of tennis players and their sensitivity to injustice, as well as its components - cognitive and emotional, are presented in Table 2. The Cronbach coefficient alphas observed in our study: extroversion $\alpha=.73$, emotional lability $\alpha=.84$, openness $\alpha=.70$, agreeableness $\alpha=.79$, and conscientiousness $\alpha=.81$. The internal consistency of the questionnaire of sensitivity to injustice - SVN was in our study $\alpha=.90$. The results of our research have

Table 1

Descriptive statistics of tennis players

\begin{tabular}{lcrrrr}
\hline & Range of the scale & Mean & $S D$ & Minimum & Maximum \\
\hline Five-factor personal inventory NEO-FFI & & & & & \\
Total score & $0-240$ & 143.90 & 16.76 & 109 & 189 \\
Emotional lability & $0-48$ & 23.07 & 9.33 & 4 & 40 \\
Extroversion & $0-48$ & 29.82 & 6.54 & 12 & 43 \\
Openness to experience & $0-48$ & 28.33 & 6.53 & 18 & 44 \\
Agreeableness & $0-48$ & 30.21 & 7.28 & 8 & 42 \\
Conscientiousness & $0-48$ & 32.93 & 6.51 & 17 & 45 \\
Questionnaire sensitivity to injustice - SVN & & & & \\
Total score & $32-128$ & 68.30 & 15.00 & 37 & 106 \\
Cognitive component & $16-64$ & 31.77 & 8.71 & 18 & 56 \\
Emotional component & $16-64$ & 36.52 & 9.18 & 18 & 56 \\
\hline
\end{tabular}

Table 2

Results of correlation analysis between the Questionnaire sensitivity to injustice - SVN and Fivefactor personal inventory NEO-FFI

\begin{tabular}{lccc}
\hline \multirow{2}{*}{ Five-factor personal } & \multicolumn{3}{c}{ Questionnaire sensitivity to injustice - SVN } \\
\cline { 2 - 4 } inventory NEO-FFI & Total score & Cognitive component & Emotional component \\
\hline Emotional lability &. $\mathbf{4 1}^{* *}$ & $.39^{* *}$ &. $\mathbf{2 9}^{*}$ \\
Extroversion & -.21 & -.07 & $-.27^{*}$ \\
Openness to experience & .08 & .01 & .13 \\
Agreeableness & -.10 & -.12 & -.06 \\
Conscientiousness & -.21 & -.20 & -.15 \\
\hline
\end{tabular}

$* p<.05, * * p<.01$. 
shown that the sensitivity to injustice varies according to the level of emotional lability/emotional stability. We have found a moderate significant relation $(r=.41$; $p=.001)$ between emotional lability of tennis players and their overall sensitivity to injustice - SVN. The tennis players being highly sensitive to injustice have a high level of emotional lability and those having low sensitivity to injustice have a high level of emotional stability. We have also found out moderate relationship between the emotional lability of the tennis players and their cognitive component of sensitivity to injustice $(r=.39 ; p=.002)$. Significant relationship has been also demonstrated between the emotional lability of tennis players and their emotional component of injustice sensitivity $(r=.29 ; p=.021)$. The results of our research also show that the level of consciousness $(r=-.21 ; p=.112)$, agreeableness $(r=-.10 ; p=.438)$, and openness to experience $(r=.08 ; p=.524)$ does not have an effect on their overall sensitivity to injustice, however the exception of the extrovert/introvert, where we have found out significant relationship for the emotional component of the sensitivity to injustice $(r=.29$; $p=.033)$.

\section{Discussion}

The assumption that there is a positive relationship between the emotional lability of tennis players and their overall sensitivity to injustice, we have confirmed what is also in accordance with the research findings of Žitný and Halama (2011). The results of our research have shown that emotionally unstable tennis players respond to unjust situations much more sensitively in comparison to emotionally stable tennis players.

A high level of emotional lability predisposes people to lower control of their behavior and experience angry reactions towards injustice in stressful situations (Hřebíčková \& Urbánek, 2001). We may characterize an emotionally unstable tennis player as highly sensitive to injustice as a non-incredulous person with tendency to negative emotion who is mainly characterized by excessive monitoring of his behavior (Demir \& Yazici, 2015; Gleason, Jensen-Campbell, \& Richardson, 2004).

We did not confirm the assumption regarding a negative relationship between the extrovertedness of tennis players and their overall sensitivity to injustice. According to the results from our research, the extrovertedness/introvertedness of tennis players has no effect on their overall sensitivity to unjust situations, with the exception of the emotional component of sensitivity to injustice, where we are able to prove a weaker but significant relationship. As is clear from the above mentioned, in the case of extrovert tennis players, their angry reactions to different stressful and tense situations have become a statistically significant indicator of injustice that is their emotional component in the case of total sensitivity to injustice. The reason for greater resistance of people of the extrovert type to situations of injustice may be their tendency to look at experience from a positive side (Allen \& Laborde, 2014; Watson \& Clark, 1992). Extroverts are more aggressive in seeking justice than introverted people (Lovaš \& Wolt, 2002). The ability of the extrovert individual to communicate openly with his feeling of injustice may lead to positive perception of unfair situations, and thus to overall reduction in their occurrence (Allen \& Laborde, 2014; Lovaš \& Wolt, 2002; Žitný \& Halama, 2011). Moreover, extrovert tennis players as they want to be accepted by the environment may significantly reduce their confluence and increase their social acceptability in comparison to introvert tennis players whose distance from others may make them more sensitive in unjust situations (Hřebíčková \& Urbánek, 2001).

The results of our research do not show that more agreeable and more conscious tennis players experience situations less sensitively than unconscious, antagonistic players, what is contrary to the research findings of Žitný and Halama (2011), experts who conducted similar research on 261 university students. The results of their research have shown a moderately negative relation in the case of agreeableness and the overall score of the questionnaire sensitivity to injustice $(r=-.41 ; p \leq .01)$ and a weak negative significant relation in case of consciousness and the overall score of sensitivity to injustice $(r=-.13 ; p \leq .05)$. On the basis of the results of our research, it is possible to assume that the difference in results may be the consequence of low representativeness of the research sample and more demanding availability.

The assumption that there is a negative relationship between openness to the experience and sensitivity to injustice situations has also failed to be confirmed. It is clear from the results of our research that the openness of tennis players to experience does not affect their individual variability towards sensitivity to injustice. Similarly, as in the case of consciousness and agreeableness, we believe that in the context of further research it would be beneficial to carry out a research of sensitivity to injustice with wider scale of sample of athletes in order to more objectively prove the presence or absence of the relation between the variables.

During our research we have also encountered certain limits. One of the limits of our research is the lack of an available sample of tennis players in early adulthood. We partially eliminated this limit by using the snow ball technique, where we contacted tennis 
players who met our criteria through tennis trainers. We consider the collected data to be representative, however in the future we recommend exploring a wider research sample and compare results with findings in collective sports.

\section{Conclusion}

The results of our research have shown that the sensitivity to injustice of tennis players varies according to the level of emotional lability/stability. The tennis players who are highly sensitive to injustice have a high level of emotional lability and those having low sensitivity to injustice have a high level of emotional stability. The results can help tennis players and their coaches better understand the situation-related aspects of human behavior in situations of injustice and timely advise problems of motivation loss and timely advise on the problems of motivation loss caused by repeated experiences of injustice.

\section{Conflict of interest}

There were no conflicts of interest.

\section{References}

Aidman, E. V. (2007). Attribute-based selection for success: The role of personality attributes in long-term predictions of achievement in sport. Journal of the American Board of Sport Psychology, 1, 3.

Allen, M. S., Greenless, I., \& Jones, M. V. (2013). Personality in sport: A comprehensive review. International Review of Sport and Exercise Psychology, 6, 184-208.

Allen, M. S., \& Laborde, S. (2014). The role of personality in sport and physical activity. Current Directions in Psychological Science, 23, 460-465.

Argyle, M., \& Lu, L. (1990). Happiness and social skills. Personality and Individual Differences, 11, 1255-1261.

Batson, C. D. (2012). The empathy-altruism hypothesis: Issues and implications. In J. Decety (Ed.), Empathy: From bench to bedside (pp. 41-54). Cambridge, MA: The MIT Press.

Baumert, A., Otto, K., Thomas, N., Bobocel, D. R., \& Schmitt, M. (2012). Processing of unjust and just information: Interpretation and memory performance related to dispositional victim sensitivity. European Journal of Personality, 26, 99-110.

Conway, B. H. (2016). Investigating the relationship between personality traits and athletic performance among elite hockey players. EWU Masters Thesis Collections, 347.

Courneya, K. S., \& Hellsten, L. A. (1998). Personality correlates of exercise behavior, motives, barriers and preferences: An application of the five-factor model. Personality and Individual Differences, 24, 625-633.

David, J. P., \& Suls, J. (1999). Coping efforts in daily life: Role of Big Five traits and problems appraisals. Journal of Personality, 67, 265-294.

Decety, J., \& Cowell, J. M. (2014). The complex relation between morality and empathy. Trends in Cognitive Sciences, 18, 337-339.

Decety, J., \& Yoder, K. J. (2016). Empathy and motivation for justice: Cognitive empathy and concern, but not emotional empathy, predict sensitivity to injustice for others. Social Neuroscience, 11, 1-14.

Demir, E., \& Yazici, E. (2015). Assessment of personality traits of performance tennis players aged 18 years and above. Scientific Research Journal, 3(2), 32-34.

Digman, J. M. (1989). Five robust trait dimensions: Development stability and utility. Journal of Personality, 57, 195-214.

Durozoi, G., \& Roussel, A. (1994). Filozofický slovník [Philosophical dictionary]. Prague, Czech Republic: EWA.

Ellis, A., \& MacLaren, C. (2005). Rational emotive behavior therapy: A therapist's guide (2nd ed.). Oakland, CA: Impact Publishers.

Gleichgerrcht, E., \& Young, L. (2013). Low levels of empathic concern predict utilitarian moral judgment. PLoS ONE, 8(4), 1-12.

Gleason, K. A., Jensen-Campbell, L. A., \& Richardson, D. S. (2004). Agreeableness as a predictor of aggression in adolescence. Aggressive Behavior, 30, 43-61.

Gregor, T. (2004). Osobnostné charakteristiky tenistov a ich vplyv na herný výkon [Personality characteristics of tennis players and their influence on game performance]. Acta Facultatis Educationis Physicae Universitatis Comenianae, 45, 93-104.

Gunthert, G. C., Cohen, L. H., \& Armeli, S. (1999). The role of neurocitism in daily stress and coping. Journal of Personality and Social Psychology, 77, 1087-1100.

Hamlin, J. K. (2014). The origins of human morality: Complex socio-moral evaluations by preverbal infants. In J. Decety \& Y. Christen (Eds.), New frontiers in social neuroscience (pp. 165-188). New York, NY: Springer.

Hřebičková, M., \& Urbánek, T. (2001). NEO Pětifaktorový osobnostní inventár [Neo-Five Factor Inventory]. Prague, Czech Republic: TestCentrum.

Jang, K. L., McCrae, R. R., Angleitner, A., Riemann, R., \& Liwesley, W. J. (1998). Heritability of facet-level traits in a cross cultural twin sample: Support for a hierarchical model of personality. Journal of Personality and Social Psychology, 74, 1556-1565.

Jensen-Campbell, L. A., \& Graziano, W. G. (2001). Agreeableness as a moderator of interpersonal conflict. Journal of Personality, 69, 323-362.

Kafka, J., Kovaničová, M., \& Pálová, E. (2004). K otázke osobnosti: základné konštrukcie, metodológia, dynamická štruktúra osobnosti [On personality issues: Basic structures, methodology, dynamic personality structure]. Psychiatria, 11, 14-21.

Lovaš, L. (1995). Nespravodlivost’ v interpersonálnych vztahoch [Injustice in interpersonal relationships]. Československá psychologie, 39, 203-212. 
Lovaš, L., \& Pirháčová, I. (1996). Anxieta, hnevlivost a senzitivita voči nespravodlivosti [Anxiety, anger, and sensitivity to injustice]. Československá psychologie, 40, 248-255.

Lovaš, L., \& Wolt, R. (2002). Sensitivity to injustice in the context of some personality traits. Studia Psychologica, 44, 125-131.

McCrae, R. R., \& Costa, P. T. (1997). Personality trait structure as a human universal. American Psychologist, 52, 509-516.

Mikula, G., \& Schlamberger, K. (1985). What people think about an unjust event: Toward a better understanding of the phenomenology of experiences of injustice. European Journal of Social Psychology, 15, 37-49.

Miller, D., Coleman, J., Connolly, W., \& Ryan, A. (Eds.). (1995). Blackwellova encyklopedie politického myšlení [The Blackwell encyclopaedia of political thought]. Brno, Czech Republic: Jota.

Mirzaei, A., Nikbakhsh, R., \& Sharififar, F. (2013). The relationship between personality traits and sport performance. European Journal of Experimental Biology, 3, 439-442.

O’Brien, T. B., \& DeLongis, A. (1996). The interactional context of problem, emotion, and relationship-focused coping: The role of the Big Five personality factors. Journal of Personality, 64, 775-813.

Pavot, W., Diener, E., \& Fujita, F. (1990). Extraversion and happiness. Personality and Individual Differences, 11, 1299-1306.

Piedmont, R., Hill, D., \& Blanco, S. (1999). Predicting athletic performance using the five-factormodel of personality. Personality and Individual Differences, 27, 769-777.
Ruisel, I., \& Halama, P. (2007). NEO pätfaktorový osobnostný inventár [Neo-Five Factor Inventory]. Prague, Czech Republic: Testcentrum-Hogrefe.

Salbot, V., Nábělová, E., \& Kaliská, L. (2012). Emocionálna sebapôsobnost: Možnosti merania dotazníku radu TEIQue [Emotional self-ability: Possibilities of measuring the TEIQue questionnaire]. In P. Halama, R. Hanák, \& R. Masaryk (Eds.), Sociálne procesy a osobnost' (pp.234-239). Bratislava, Slovak Republic: Slovak Academy of Sciences.

Schmidt, M. F. H., \& Sommerville, J. A. (2011). Fairness expectations and altruistic sharing in 15-month-old human infants. PloS ONE, 6(10), e23223.

Wagstaff, C. (2014). Emotion regulation and sport performance. Journal of Sport Exercise Psychology, 36, 401-412.

Watson, D., \& Clark, L. A. (1992). On traits and temperament: General and specific factors of emotional experience and their relation to the five-factor model. Journal of Personality, 60, 441-476.

Wijn, R., \& van den Bos, K. (2010). Toward a better understanding of the justice judgment process: The influence of fair and unfair events on state justice sensitivity. European Journal of Social Psychology, 40, 1294-1301.

Wilson, D. (2001). Key behavioural characteristics of successful juniors. ITF Coaching \& Sport Science Review, 25, 2-3.

Yoder, K. J., Porges, E. C., \& Decety, J. (2015). Amygdala subnuclei connectivity in response to violence reveals unique influences of individual differences in psychopathic traits in a nonforensic sample. Human Brain Mapping, 36, 1417-1428.

Žitný, P., \& Halama, P. (2011). Self-esteem, locus of control and personality traits as predictors of sensitivity to injustice. Studia Psychologica, 53, 27-40. 